\title{
A mitogenomic approach to the taxonomy of pollocks: Theragra chalcogramma and $T$. finnmarchica represent one single species
} Anita Ursvik¹, Ragna Breines ${ }^{1}$, Jørgen Schou Christiansen², SveinErik Fevolden $^{2}$, Dag H Coucheron ${ }^{1}$ and Steinar D Johansen*1,3

\author{
Address: ${ }^{1}$ Department of Molecular Biotechnology, Institute of Medical Biology, University of Tromsø, N-9037 Tromsø, Norway, ${ }^{2}$ Department of \\ Aquatic BioSciences, Norwegian College of Fishery Science, University of Troms $ø$, N-9037 Tromsø, Norway and ${ }^{3}$ Department of Fisheries and \\ Natural Sciences, Bodø University College, N-8049 Bodø, Norway \\ Email: Anita Ursvik - Anita.Ursvik@fagmed.uit.no; Ragna Breines - Ragna.Breines@fagmed.uit.no; \\ Jørgen Schou Christiansen - jch000@nfh.uit.no; Svein-Erik Fevolden - sfe000@nfh.uit.no; Dag H Coucheron - dagc@fagmed.uit.no; \\ Steinar D Johansen* - Steinar.Johansen@fagmed.uit.no \\ * Corresponding author
}

Published: 7 June 2007

BMC Evolutionary Biology 2007, 7:86 doi:10.1/86/147|-2/48-7-86
Received: 3 November 2006

Accepted: 7 June 2007

This article is available from: http://www.biomedcentral.com/147I-2/48/7/86

(C) 2007 Ursvik et al; licensee BioMed Central Ltd.

This is an Open Access article distributed under the terms of the Creative Commons Attribution License (http://creativecommons.org/licenses/by/2.0), which permits unrestricted use, distribution, and reproduction in any medium, provided the original work is properly cited.

\begin{abstract}
Background: The walleye pollock (Theragra chalcogramma) and Norwegian pollock (T. finnmarchica) are confined to the North Pacific and North Atlantic Oceans, respectively, and considered as distinct species within the family Gadidae. We have determined the complete mtDNA nucleotide sequence of two specimens of Norwegian pollock and compared the sequences to that of 10 specimens of walleye pollock representing stocks from the Sea of Japan and the Bering Sea, 2 specimens of Atlantic cod (Gadus morhua), and 2 specimens of haddock (Melanogrammus aeglefinus).

Results: A total number of 204 variable positions were identified among the 12 pollock specimens, but no specific substitution pattern could be identified between the walleye and Norwegian pollocks. Phylogenetic analysis using 16.500 homologous mtDNA nucleotide positions clearly identify the Norwegian pollock within the walleye pollock species cluster. Furthermore, the Norwegian pollock sequences were most similar to mitochondrial genotypes present in walleye pollock specimens from the Sea of Japan, an observation supported both by neighbor-joining, maximum parsimony, and maximum likelihood analyses.
\end{abstract}

Conclusion: We infer that walleye pollock and Norwegian pollock represent one single species and that Norwegian pollock has been recently introduced from the Pacific to the Atlantic Oceans.

\section{Background}

The walleye pollock (Theragra chalcogramma) is a commercially important codfish species confined to the North Pacific Ocean from the Sea of Japan to the Gulf of Alaska [1]. The population structure of walleye pollock has been investigated by the use of various genetic markers including allozymes, microsatellites, and mitochondrial DNA sequences. The structuring is still unclear despite identification of distinct stocks in geographic regions including Sea of Japan, Sea of Okhotsk, Bering Sea, and Gulf of Alaska [2-5]. The Norwegian pollock (T. finnmarchica) is a very rare codfish species that was first discovered and described in 1932, and with a geographical distribution restricted to coastal regions of northern Norway for all the 
ca 50 specimens so far recorded [6]. The Norwegian pollock closely resemble the walleye pollock, but previous comparative examinations of morphological features have concluded that the two pollocks represent distinct species $[7,8]$.

Mitogenomics is a high-resolution molecular genetic approach that includes the complete mitochondrial genome sequence (ca $16.500 \mathrm{bp}$ ) in the analyses. Mitogenomics, combined with molecular phylogenetics, has successfully resolved controversial issues of the origin and genetic variation of modern humans $[9,10]$, as well as phylogenetic relationships among closely related fish species $[11,12]$. In the present study we have performed analysis that includes the complete mitochondrial genome sequences from multiple individuals of Norwegian pollock (T. finnmarchica), walleye pollock (T. chalcogramma), Atlantic cod (Gadus morhua) and haddock (Melanogrammus aeglefinus) in order to resolve the controversial relationship of the Theragra species.

\section{Results}

The complete mitochondrial genome sequence was determined for two individuals of Norwegian pollock ( $T$. finnmarchica), as well as one new individual each of Atlantic cod (G. morhua) and haddock (M. aeglefinus) (Table 1). The mtDNAs were approximately $16.6 \mathrm{~kb}$ in length with identical gene content and organization (13 protein coding genes, 2 ribosomal RNA genes, and 22 transfer RNA genes; Fig 1A) compared to previously published sequences in Atlantic cod, walleye pollock and haddock [13-15]. Heteroplasmy was detected in the ETAS (extended termination associated sequence) region within the control region in both Atlantic cod and Norwegian pollock. Atlantic cod mtDNA contains a heteroplasmic tandem repeat (HTR) motif of 40 bp that vary in copy number from 2-5 [16,17]. Heteroplasmy at single sites corresponding to that observed in walleye pollock [14] was also found in Norwegian pollock mtDNA. Thus, the ETAS region was excluded in subsequent phylogenetic analyses.

Nucleotide substitutions and deletions were assessed by comparing the complete mtDNA sequence of the 12 pollock specimens. The total number of variable sites identified was 204, and include all protein coding and ribosomal RNA genes, the control region (D-loop), and 2 of the 22 transfer RNA genes (Fig 1B). Transition substitutions at third codon positions of protein coding genes were the most common changes, and nucleotide deletions were only observed at one site in the SSU rRNA gene as well as in the ETAS region of the control region. However, no specific substitution feature could be identified in any of the Norwegian pollock sequences in comparison to that of the walleye pollock sequences, including no unique sites that distinguished the two proposed pollock species. Yanagimoto et al. [14] identified a single nucleotide polymorphism in the ND4 gene as a diagnostic marker of pollocks from the Sea of Japan and the Bering Sea. Interestingly, both the Norwegian pollock specimens harbour the Sea of Japan-type of nucleotide at this position (C11578 in the TF 19 sequence, Fig 1B).

A total of 16.500 nucleotide positions were unambiguously aligned from 16 specimens representing Norwegian pollock ( 2 specimens), walleye pollock (10 specimens), Atlantic cod (2 specimens), and haddock (2 specimens). The two specimens of Atlantic cod and haddock were selected in order to represent distant geographic locations (eastern and western Atlantic for G. morhua, and North Sea and northern Norway for M. aeglefinus). Pair wise distance within and between species are given in Table 2. In all cases, except for the two pollock species, interspecific p-distances were found to be significantly higher (approx. $10 \times)$ than distances within a defined species. Here, p-distances among the Atlantic cod specimens and the haddock specimens are 0.005 and 0.009 , respectively, which are similar to that of the 12 pollock specimens (range $0.002-0.005)$. The p-distances between genera are about 10 fold higher. This observation in the mitochondrial DNA sequence is consistent with the conclusion that Norwegian pollock and walleye pollock are not genetically distinct.

Phylogenetic analysis of the complete mitochondrial genome data-set using maximum likelihood (ML), Neighbor-joining $(\mathrm{NJ})$, and maximum parsimony (MP), all resulted in a very similar tree topology (Fig. 2) with high statistical supports. Interesting findings noted from the complete mtDNA analysis are that the two Norwegian pollock sequences cluster together with those of walleye Pollock, and that the two Norwegian pollock sequences are more closely related to walleye pollock sequences isolated from specimens in the Sea of Japan (J3 and J4) than any of the specimens from the Bering Sea. From the mitogenomic phylogeny analysis we infer that Norwegian pollock and walleye pollock have to be considered as one single species. The data implicates that the genus Theragra consists of only one species confined to both the North Atlantic and North Pacific Oceans, a situation similar to that proposed for the Pacific cod (G. macrocephalus) and Greenland cod (G. ogac) based on partial mtDNA sequence analysis [18]. Although the genetic data are unequivocal, recent and extensive morphological examination of Theragra suggest that the formal taxonomic designations are upheld, but at the subspecific level (SEF, unpublished results). 
Table I: Key features of Gadidae specimens and complete mtDNA sequences

\begin{tabular}{|c|c|c|c|}
\hline Name & Specimen; Location & mtDNA accession no. & Reference \\
\hline Theragra finnmarchica (Norwegian pollock) & Tf 19; Norwegian coastal & AM4897I8 & This work \\
\hline T. finnmarchica & Tf 2I; Norwegian coastal & AM4897I9 & This work \\
\hline T. chalcogramma (Walleye pollock) & JI; Sea of Japan & $A B \mid 82300$ & [14] \\
\hline T. chalcogramma & J2; Sea of Japan & $A B \mid 82301$ & [14] \\
\hline T. chalcogramma & J3; Sea of Japan & $A B \mid 82302$ & {$[14]$} \\
\hline T. chalcogramma & J4; Sea of Japan & $A B \mid 82303$ & {$[14]$} \\
\hline T. chalcogramma & J5; Sea of Japan & $A B \mid 82304$ & [14] \\
\hline T. chalcogramma & BI; Bering Sea & AB09406I & {$[14]$} \\
\hline T. chalcogramma & B2; Bering Sea & $A B \mid 82305$ & {$[14]$} \\
\hline T. chalcogramma & B3; Bering Sea & $A B \mid 82306$ & [14] \\
\hline T. chalcogramma & B4; Bering Sea & $A B \mid 82307$ & {$[14]$} \\
\hline T. chalcogramma & B5; Bering Sea & $A B \mid 82308$ & [14] \\
\hline Gadus morhua (Atlantic cod) & $\mathrm{NCl}$; Norwegian coastal & X99772 & {$[13]$} \\
\hline G. morhua & NFI; Newfoundland & AM4897I6 & This work \\
\hline Melanogrammus aeglefinus (Haddock) & NS; North Sea & DQ020497 & {$[15]$} \\
\hline M. aeglefinus & Nol; Norwegian coastal & AM4897I7 & This work \\
\hline
\end{tabular}

\section{Discussion}

Our finding that the Norwegian pollock appears recently derived from walleye pollock lineages within the Sea of Japan, is puzzling. One possibility is that a subpopulation of walleye pollock migrated from the North Pacific Ocean into the North Atlantic Ocean through the Bering Strait and Arctic Ocean, the only plausible connection between the Pacific and Atlantic Oceans in the Northern Hemisphere. If so, the Norwegian pollock would be expected to be more genetically similar to walleye pollock from the Bering Sea than that from the Sea of Japan due to geographical distances. However, this assumption is not supported in our analysis. Furthermore, walleye pollock has not been reported in the Arctic Ocean, between the Bering Strait and coast of Norway, despite intense fishery activities over years [19]. Alternatively, walleye pollock could have been introduced (intentionally or unintentionally) by human to the northeast Atlantic from the Sea of Japan. In fact, the Soviet Russian authorities did some experiments around 1930 on transfer of marine species by railway from Vladivostok to Murmansk (see http:// www.kartesh.com/texts/text.php?uid=46773), but currently there are no available documentations that include walleye pollock. Whatever the reason may be, the pres- ence of a small population of pollock in the North Atlantic Ocean is a very interesting observation and should be included in ecosystem monitoring approaches [20] of the Arctic Ocean.

\section{Conclusion}

Based on the complete mitochondrial genome sequences we conclude that the walleye pollock (Theragra chalcogramma) and Norwegian pollock (T. finnmarchica) represent one single species, and that Norwegian pollock has been recently introduced from the Pacific to the Atlantic Oceans.

\section{Methods}

\section{Fish samples and DNA extraction}

Specimens of T. finnmarchica (Tf. 19 and Tf. 21) were collected at May 11, 2003 and April 29, 2003, respectively, in Norwegian coastal waters east of the North Cape. The G. morhua specimen was collected off Newfoundland, Canada (NF1), and the M. aeglefinus specimen (No1) was collected off the coast of northern Norway. Key-features of fish samples and mitochondrial DNA sequences used in this study are listed in Table 1. DNA was extracted from muscle tissue by using the mtDNA Extractor CT Kit from

Table 2: Summary of p-distances between and within species based on $16.500 \mathrm{nt}$ positions

\begin{tabular}{lll}
\hline Species & No. specimens & P-distance (range) \\
\hline Theragra finnmarchica & 2 & 0.002 \\
T. chalcogramma & 10 & $0.002-0.005$ \\
Gadus morhua & 2 & 0.005 \\
Melanogrammus aeglefinus & 2 & 0.009 \\
T. finnmarchica/T. chalcogramma & $2 / 10$ & $0.003-0.004$ \\
Theragra/G. morhua & $12 / 2$ & $0.039-0.041$ \\
Theragra/M. aeglefinus & $12 / 2$ & $0.082-0.083$ \\
G. morhua/M. aeglefinus & $2 / 2$ & 0.084
\end{tabular}



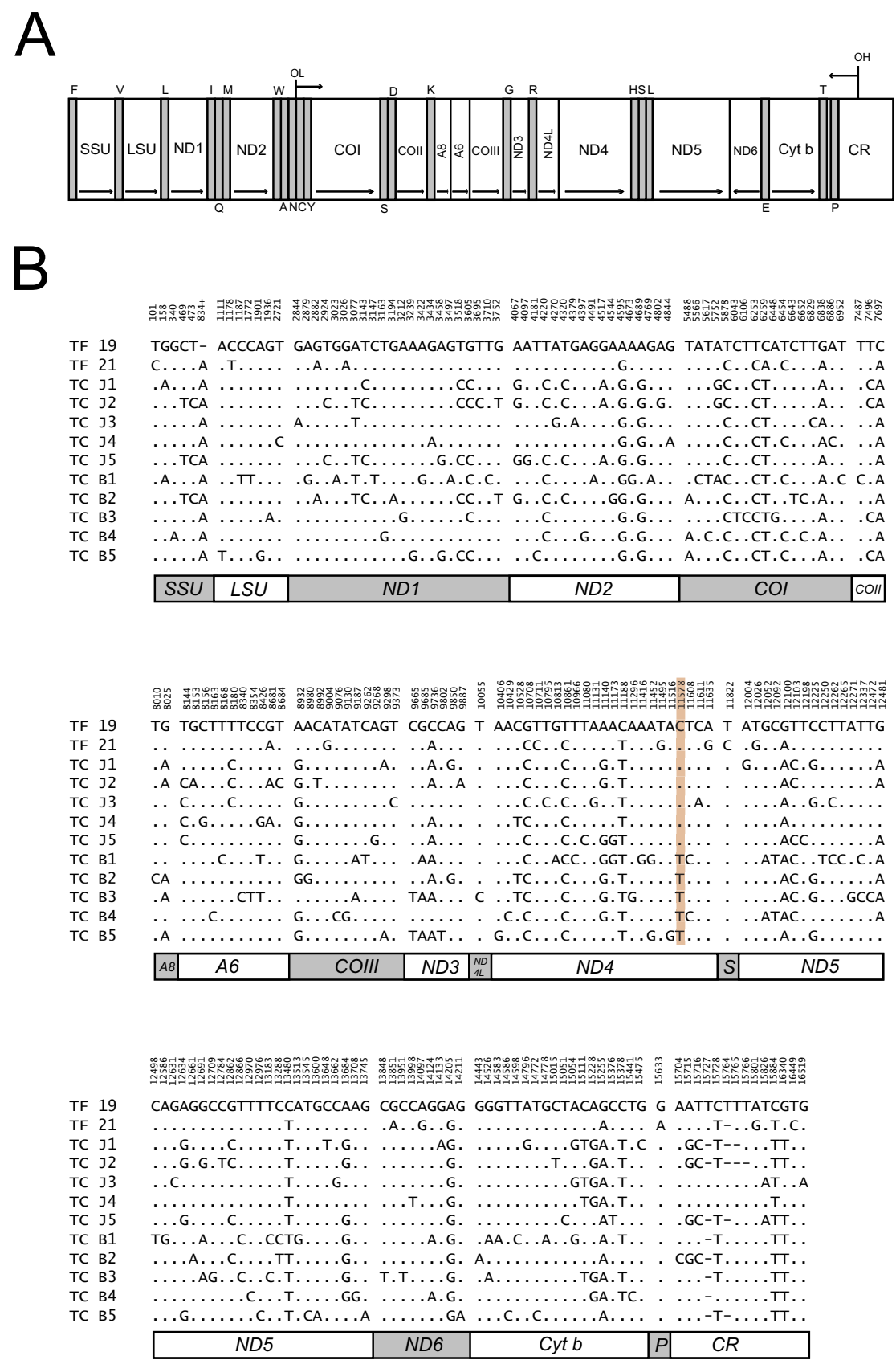

\section{Figure I}

Gene content, organization, and variability of Theragra mitochondrial genomes. (A) Linear map of the circular mtDNA. All genes, except ND6 and 8 of the transfer RNA genes (indicated by the standard one-letter symbols for amino acid below the diagram), are encoded by the $\mathrm{H}$-strand. Abbreviations: SSU and LSU, mitochondrial small- and large-subunit ribosomal RNA genes; NDI-6, NADH dehydrogenase subunit I to 6; COI-III, cytochrome c oxidase subunit I to III; A6 and A8, ATPase subunit 6 and 8; Cyt b, cytochrome b; OH and OL, origin of $\mathrm{H}$-strand and L-strand replication; CR, control region containing the D-loop. (B) Distribution of variable sites in pollock mtDNA numbered according to the sequence of the Norwegian pollock Tf 19 (AM4897I8, Table I). The position 834+ in SSU rDNA indicates nucleotide insertion between positions 834 and 835 in Tf 19. The variable sites were aligned to that of Tf 19. Identical sites are indicated by dots and deletions by dashes. The proposed diagnostic single nucleotide polymorphism at ND4 of Sea of Japan and Bering Sea pollocks [I4] is boxed at position II578. 

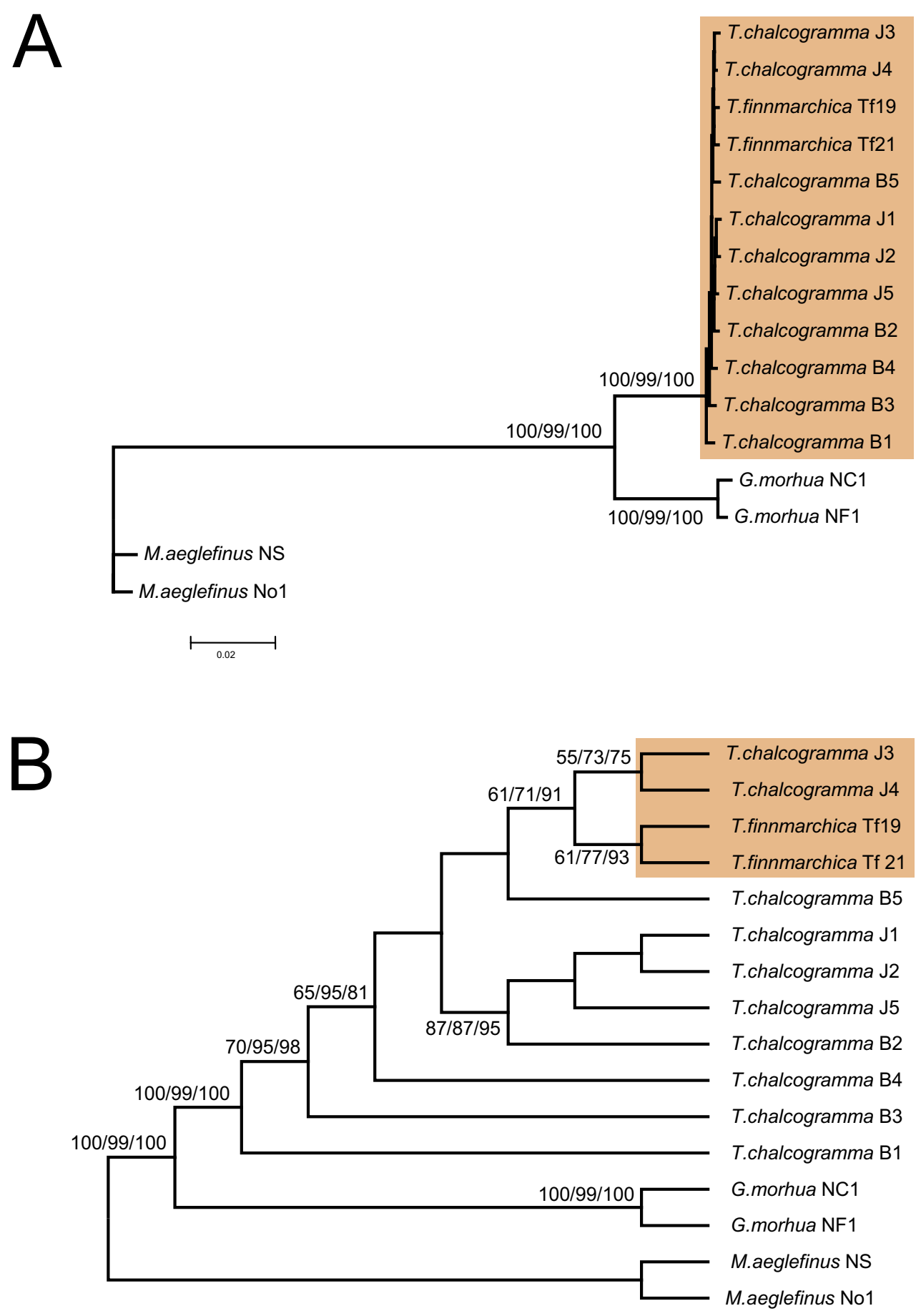

Figure 2

Phylogenetic relationship of Theragra. (A) Maximum-likelihood (ML) phylogenetic tree based on 16.500 nucleotide positions and the $T M V+I+G$ evolutionary model. Trees constructed by neighbour-joining ( $N$ J, Jukes-Cantor substitution model) and maximum parsimony (MP, heuristic searches) displayed almost identical topologies with the ML tree. Bootstrap values (2000 replications) are shown at the branches (ML/MP/NJ). Theragra sequences are boxed. (B) Tree presenting the topology (same ML tree as in A) with bootstrap values (2000 replications) over $50 \%$ at the branches (ML/MP/NJ). The relationship between $T$. finnmarchica and the two speciemens J3 and J4 of $T$. chalcogramma from the Sea of Japan are boxed. 
Table 3: PCR and DNA sequencing primers

\begin{tabular}{|c|c|}
\hline Primer & Sequence (5', 3') \\
\hline L42 & GAT GGA CCC TAG AAA GTC C \\
\hline $\mathrm{HI}$ & AGA TGT GCC TGA TAC CTG CT \\
\hline L290 & GAA AGC TTG ACT TAG TTA AG \\
\hline $\mathrm{H} 4 \mathrm{I} 4$ & TGA CTT CGG ATG CGT ATA AC \\
\hline $\mathrm{H} 617$ & TAG AAC AGG CTC CTC TAG \\
\hline LI 223 & CGC AAG GGA ACG CTG AAA \\
\hline $\mathrm{HI} 275$ & AGG TAC GAG TAG AAA ACT CTG \\
\hline LI 757 & CTT ACC AGG CTG TCT TAT GC \\
\hline HI805 & GTC CGT TCC GAC TTA CAC \\
\hline L2222 & ATT ACA TAA GAC GAG AAG AC \\
\hline L3089 & GCC AGT ACT TGC ACT AAC TC \\
\hline $\mathrm{H} 3562$ & AGC CCA GAA ATA GTA CAG CT \\
\hline L3760 & TGG CAC TAG TGA TTT GAC AT \\
\hline L4366 & GTA CAC TTC TGG TTA CCA GA \\
\hline $\mathrm{H} 4559$ & AGC CAA GAT GTG CGA TTG AT \\
\hline L4876 & TAA GCC TTT ACT TTT ATC T \\
\hline L5232 & СTC TTA GTT AAC AGC TAA GC \\
\hline H5475 & AGG GTG CCA ATG TCT TTG TG \\
\hline L5572 & TCG AGC AGA GCT AAG TCA AC \\
\hline L6604 & ATG TAT AGG AGC TGT CTT TG \\
\hline $\mathrm{H} 6880$ & TCA ACT GCT ATT ACT TCC CG \\
\hline L7208 & ATC ACC CGT AAT AGA AGA GT \\
\hline L790 I & TGG AAG CAG GTG ACT CCC AA \\
\hline H8439 & ATG ACC TAG TGC ATG AGT TG \\
\hline L8575 & TTA CAG CTA ATC TTA CAG CA \\
\hline L9302 & TTC AAG GAC TGG AGT ACT AT \\
\hline $\mathrm{H} 10545$ & TGA CTT GCA AGG AGT ATT AG \\
\hline LII407 & GAC CAC ATG ATG ATT TAT TG \\
\hline LI0603 & TAT AAA CCG CCA ACG TA \\
\hline $\mathrm{HII} / 4$ & ATC TAA TGT CTT GGT TA \\
\hline HII 887 & ACT TGG AGT TGC ACC AAG AG \\
\hline $\mathrm{L}|2| 2 \mid$ & TAT AGA GGC TGT AAC TTC TT \\
\hline $\mathrm{H} 13913$ & GTG AGT ACC TGT AGA TGA GT \\
\hline LI433I & CCA CCG TTG TTA TTC AAC T \\
\hline $\mathrm{HI} 4746$ & AAT TAC GGT AGC TCC TCA GAA TGA TAT TTG TCC TCA \\
\hline LI5246 & TAT TCT CCA TTC TAG TCC TT \\
\hline LI5250 & CTC GAT TCT AGT CCT CAT GG \\
\hline LI5500 & ACT GAG CTA CTA GGG CAG TTT C \\
\hline HI5666 & GTT TAA TTT AGA ATT CTA GCT TTG G \\
\hline $\mathrm{H} 16180$ & GAA TAG CCA GGA AAC GTG TTA \\
\hline $\mathrm{HI} 6390$ & AAC CGA GGA CTA GCT CCA CC \\
\hline SP6 & GATTTAGGTGACACTATAG \\
\hline T7 & AATACGACTCACTATAG \\
\hline
\end{tabular}

Wako. The method makes use of differential centrifugation steps to obtain a crude isolation of the mitochondria in the membrane fraction, lysis of the mitochondria, and subsequent precipitation of the supernatant with sodium iodide and isopropanol.

\section{PCR amplification, cloning, and DNA sequencing}

Primers (Table 3) designed from our published Atlantic cod mtDNA sequence (X99772) [13] were used to amplify $1-4 \mathrm{~kb}$ fragments using one heavy $(\mathrm{H})$ and one light $(\mathrm{L})$ strand primer. Each PCR reaction $(25 \mu \mathrm{l})$ included solution, $0.2 \mathrm{mM}$ dNTPs, $0.2 \mu \mathrm{M}$ of each primer and $0.6 \mathrm{U}$ of
Expand HiFidelity polymerase and buffer (Roche) in addition to the total DNA sample. The PCR reactions were performed in a Peltier 200 Thermal cycler with the following cycling parameters: $94^{\circ} \mathrm{C}$ initial denaturation for $2 \mathrm{~min}$, 30 cycles with $94^{\circ} \mathrm{C}$ denaturation for $15 \mathrm{sec}, 53^{\circ} \mathrm{C}$ annealing for $30 \mathrm{sec}, 68^{\circ} \mathrm{C}$ elongation for $2-3 \mathrm{~min}$, and finally $72^{\circ} \mathrm{C}$ for $7 \mathrm{~min}$. The total volumes were run on 0.8 or $1 \%$ agarose gels containing ethidium bromide, and bands were excised and purified with Qiagen gel extraction kit. When appropriate, PCR products were inserted into the pDrive vector (Qiagen) and transformed in E. coli EZ competent cells. Positive clones were verified with plasmid 
isolation (Wizard plasmid purification kit) and EcoRI restriction cutting followed by agarose gel electrophoresis. In general, PCR products were sequenced on both strands by using the BigDye version 3.1 kit (Applied Biosystems) with the same primers as in the PCR and internal primers (Table 3 ). The reaction mixture included $10-60 \mathrm{ng}$ of the PCR-template, $0,35 \mu \mathrm{M}$ primer, $2 \mu \mathrm{l}$ BigDye mix, $1 \mu \mathrm{l} 5 \times$ reaction buffer in a $10 \mu \mathrm{l}$ volume. The sequencing products were analysed by an ABI genetic analyser (Applied Biosytems).

\section{Data analysis}

In general, computer analyses of DNA sequences were performed using software package programs from DNASTAR Inc. For the phylogenetic analyses, nucleotide sequences based on 16.500 positions covering the complete mitochondrial genomes except the highly variable ETAS, were used to make a multiple alignment as one single dataset using ClustalX version 1.81 [21] and manual refinements. MEGA version 3.1 [22] was used to estimate pairwise distances using the uncorrected p-distance model. Furthermore, MEGA was used to construct trees with the methods of neighbor joining (NJ) using different distance matrices, and maximum parsimony (MP) with heuristic searches using close-neighbor-interchang (CNI) level 3 and production of initial trees by of random addition of sequences (100 replicates). Maximum likelihood (ML) analyses, based on the sequence evolution model $\mathrm{TMV}+\mathrm{G}+\mathrm{I}$ selected by the program WinModeltest version 4b [23], were conducted with PAUP* (version 4.0 b10) [24]. The reliability of tree branching points was assessed by bootstrapping (2000 replications).

\section{Authors' contributions}

$\mathrm{AU}$ and $\mathrm{RB}$ did the sequencing of the mitochondrial genomes. DHC performed the phylogenetic analysis. DHC, SDJ, AU, and RB contributed to mtDNA sequence analyses. JSC and SEF contributed with fish samples and valuable discussions. SDJ directed the research and wrote the paper in collaboration with DHC.

\section{Acknowledgements}

We thank Marianne Nymark for technical assistance, and Dr. Sherrylynn Rowe, Bedford Institute of Oceanography, for providing the Newfoundland Atlantic cod sample. This work was supported by grants from the Norwegian Research Council, University of Tromsø, Bodø University College, and the MABIT (Marine Biotechnology in Northern Norway) program.

\section{References}

I. Bailey KM, Stabeno PJ, Powers DA: The role of larval retention and transport features in mortality and potential gene flow of walleye pollock. J Fish Biol 1997, 5 I: I 35- I55.

2. Bailey KM, Quinn TJ II, Bentzen P, Grant WS: Population structure and dynamics of walleye pollock, Theragra chalcogramma. Adv Mar Biol 1999, 37:179-255.

3. Olsen JB, Merkouris SE, Seeb JE: An examination of spatial and temporal genetic variation in walleye pollock (Theragra chalcogramma) using allozyme, mitochondrial DNA, and microsatellite data. Fishery Bulletin 2002, 100:752-764.
4. O'Reilly PT, Canino MF, Bailey KM, Bentzen P: Inverse relationship between Fst and microsatellite polymorphism in the marine fish, walley pollock (Theragra chalcogramma): implications for resolving weak population structure. Mol Ecol 2004, 13:1799-18|4.

5. Grant WS, Spies IB, Canino MF: Biogeographic evidence for selection on mitochondrial DNA in North Pacific walleye pollock Theragra chalcogramma. J Heredity 2006, 97:57I-580.

6. Christiansen JS, Fevolden S-E, Byrkjedal I: The occurrence of Theragra finnmarchica Koefoed 1956 (Teleostei, Gadidae), 1932 2004. J Fish Biol 2005, 66: I 193-I I 97.

7. Koefoed E: Theragra finnmarchica, n. sp. A fish caught off Berlevåg allied to the Alaskan pollock, Theragra chalcogramma Pallas from the Bering Sea. Fiskeridirektoratets Skrifter Serie Havundersøkelser 1956, I I:3-7.

8. Svetovidov AN: On the occurrence of the genus Theragra in the Barents Sea in connection with some problems of the derivation of the amphiboreal gadoids and clupeoids. Zoological Journal 1959, 38:449-464. (in Russian)

9. Ingman M, Kaessmann H, Paabo S, Gyllensten U: Mitochondrial genome variation and the origin of modern humans. Nature 2000, 408:708-13.

10. Tanaka M, Cabrera VM, Gonzalez AM, Larruga JM, Takeyasu T, Fuku N, Guo LJ, Hirose R, Fujita Y, Kurata M, Shinoda K, Umetsu K, Yamada Y, Oshida Y, Sato Y, Hattori N, Mizuno Y, Arai Y, Hirose N, Ohta S, Ogawa O, Tanaka Y, Kawamori R, Shamoto-Nagai M, Maruyama W, Shimokata $H$, Suzuki R, Shimodaira H: Mitochondrial genome variation in eastern Asia and the peopling of Japan. Genome Res 2004, 14:1832-1850.

II. Doiron S, Bernatchez L, Blier PU: A comparative mitogenomic analysis of the potential adaptive value of Arctic charr mtDNA introgression in brook charr populations (Salvelinus fontinalis Mitchill). Mol Biol Evol 2002, I9:1902-1909.

12. Minegishi Y, Aoyama J, Inoue JG, Miya M, Nishida M, Tsukamoto K: Molecular phylogeny and evolution of the freshwater eels genus Anguilla based on the whole mitochondrial genome sequences. Mol Phylogenet Evol 2005, 34: I34- 46.

13. Johansen S, Bakke I: The complete mitochondrial DNA sequence of Atlantic cod (Gadus morhua): relevance to taxonomic studies among codfishes. Mol Mar Biol Biotechnol 1996, 5:203-2।4.

14. Yanagimoto T, Kitamura T, Kobayashi T: Complete nucleotide sequence and variation of mitochondrial DNA from 10 individuals of walleye Pollock, Theragra chalcogramma. Fisheries Science 2004, 70:885-895.

15. Roques S, Fox CJ, Villasana MI, Rico C: The complete mitochondrial genome of the whiting, Merlangius merlangius, and the haddock, Melanogrammus aeglefinus: a detailed genomic comparison among closely related species of the Gadidae family. Gene 2006, 383:12-23.

16. Johansen S, Guddal PH, Johansen T: Organization of the mitochondrial genome of Atlantic cod, Gadus morhus. Nucleic Acids Res 1990, 18:41|-419.

17. Arnason E, Rand DM: Heteroplasmy of short tandem repeats in mitochondrial DNA of Atlantic cod, Gadus morhua. Genetics 1992, 132:21।-220.

18. Coulson MW, Marshall HD, Pepin P, Carr SM: Mitochondrial genomics of gadine fishes: implications for taxonomy and biogeographic origins from whole-genome data sets. Genome 2006, 49: III I5-II30.

19. Andriyashev AP, Chernova NV: Annotated list of fishlike vertebrates and fish of the Arctic Sea and adjacent waters. Journal of Ichthyology 1995, 35:8I-I23.

20. Smetacek V, Nicol S: Polar ocean ecosystems in a changing world. Nature 2005, 437:362-368.

21. Thompson JD, Gibson TJ, Plewniak F, Jeanmougin F, Higgins DG: The ClustalX windows interface: flexible strategies for multiple sequence alignment aided by quality analysis tools. Nucleic Acids Res 1997, 24:4876-4882.

22. Kumar S, Tamura K, Nei M: MEGA3: Integrated software for Molecular Evolutionary Genetics Analysis and sequence alignment. Briefings in Bioinformatics 2004, 5: 150-163.

23. Posada D, Crandall KA: Modeltest: testing the model of DNA substitution. Bioinformatics 1998, 14:8I7-81. 
24. Swofford DL: PAUP*. Phylogenetic analysis using parsimony (and other methods). Version 4. Sunderland, MA, Sinauer and Associates; 2002.

Publish with Bio Med Central and every scientist can read your work free of charge

"BioMed Central will be the most significant development for disseminating the results of biomedical research in our lifetime. " Sir Paul Nurse, Cancer Research UK

Your research papers will be:

- available free of charge to the entire biomedical community

- peer reviewed and published immediately upon acceptance

- cited in PubMed and archived on PubMed Central

- yours - you keep the copyright

Submit your manuscript here:

http://www.biomedcentral.com/info/publishing_adv.asp 